\title{
ARTYKUŁY
}

\section{GENEZA KOŁA KRAKOWSKIEGO}

\begin{abstract}
Streszczenie. Artykuł poświęcony jest charakterystyce kulturowego tła manifestu koła krakowskiego i jego zespołu, który stanowili: Józef Maria Bocheński OP, Jan Franciszek Drewnowski, ks. Jan Salamucha oraz Bolesław Sobociński, i który był wspierany przez Jana Łukasiewicza i ks. Konstantego Michalskiego. Manifestem koła była aplikacja programu szkoły lwowsko-warszawskiej do katolickiej teologii i filozofii. W tym przedsięwzięciu szczególną rolę odegrała Łukasiewicza wersja programu. Do zastosowanych środków należały: (a) odnowienie języka tak, aby spełniał on wszystkie warunki właściwego dyskursu naukowego, (b) recepcja logiki matematycznej, (c) uwspółcześnienie semiotyki i metodologii oraz (d) wykorzystanie metod formalnych. Analizowane są cztery grupy okoliczności będące środowiskiem koła krakowskiego: (a) esprit de l'époque, (b) sytuacja w filozofii, (c) sytuacja w logice i (d) sytuacja w teologii - na początku XX wieku - w bezpośrednim związku z decydującymi działaniami czterech założycieli koła.
\end{abstract}

Słowa kluczowe: koło krakowskie, szkoła lwowsko-warszawska, metodologia teologii, neoscholastyka

1. Wstęp. 2. Program koła krakowskiego. 3. Esprit de l'époque. 4. Sytuacja w filozofii. 5. Sytuacja w logice. 6. Teologiczny manifest koła krakowskiego. 7. Sytuacja w teologii.

\section{WSTĘP}

Koło krakowskie zostało założone na początku roku 1934 (a nie jak się często uznaje - w sierpniu roku 1936) przez Józefa Marię Bocheńskiego OP, Jana Franciszka Drewnowskiego, ks. Jana Salamuchę i Bolesława Sobocińskiego, pod auspicjami Jana Łukasiewicza i ks. Konstantego Michalskiego, jako katolicka odnoga szkoły lwowsko-warszawskiej ${ }^{4}$. Koło było konstytuowane przez świado-

4 Tezę tę usiłuję szczegółowo uzasadnić w pracy Cracow Circle. Theology in the Lvov-Warsaw School, w: The Significance of the Lvov-Warsaw School in the European Culture, red. A. Brożek, F. Stadler, J. Woleński, Springer, Wien 2017, 173-188. 
mie przyjęty i podany do publicznej wiadomości program, decyzję współpracy i wspólne działania podejmowane w ramach przyjętego programu. Wybuch drugiej wojny światowej we wrześniu 1939 r. wyznacza kres istnienia koła, ponieważ wspólna niemiecka i rosyjska napaść i okupacja Polski doprowadziła do unicestwienia zorganizowanego polskiego życia kulturalnego. W tym czasie Salamucha zginął śmiercią męczeńską z rąk żołnierzy niemieckich w roku 1944, a pozostali członkowie koła ulegli rozproszeniu i nie wznowili współpracy po wojnie, można by więc co najwyżej mówić wtedy o post-historii koła ${ }^{5}$. Wyznaczenie kresu istnienia koła krakowskiego na 1 września 1939 r. ma mocne podstawy przedmiotowe, zgadza się też z przyjętą przez Jana Woleńskiego periodyzacją historii całej szkoły lwowsko-warszawskiej6.

\section{PROGRAM KOŁA KRAKOWSKIEGO}

Założyciele koła krakowskiego uważali samych siebie za myślicieli katolickich oraz za reprezentantów szkoły lwowsko-warszawskiej. Wydawało im się to możliwe, ponieważ uważali program szkoły lwowsko-warszawskiej za w zasadzie metodyczny oraz neutralny $z$ uwagi na podejmowaną problematykę i akceptowane tezy merytoryczne, a myśl katolicką za wyznaczoną w zasadzie tylko przez problematykę i przez akceptowane tezy oraz za neutralną pod względem stosowanych metod. Program koła krakowskiego przewidywał zatem jako cel ostateczny

wdrożenie programu szkoły lwowsko-warszawskiej w katolickich instytucjach teologicznych i filozoficznych. (1a)

5 M. Tkaczyk, Cracow Circle. Theology in the Lvov-Warsaw School, dz. cyt.; J. Woleński, Józef M. Bocheński i Koło Krakowskie, w: Poza logika jest tylko absurd, red. D. Łukasiewicz, R. Mordarski, Kraków 2014, 29-46.

6 J. Woleński, Filozoficzna szkoła Iwowsko-warszawska, Warszawa 1985, 27. 
Początek szkoły lwowsko-warszawskiej wyznacza przyjazd Kazimierza Twardowskiego do Lwowa i objęcie przez niego profesury nadzwyczajnej na katedrze filozofii Uniwersytetu Jana Kazimierza 15 listopada 1885, po uzyskaniu w roku 1894 habilitacji w Wiedniu, w którym studiował pod kierunkiem Franza Brentany? Twardowski świadomie dążył do stworzenia polskiego ośrodka filozofii naukowej, dość ostro odróżnianej od światopoglądu, literatury etc. Pod tym względem jego szkoła była bliska brytyjskiej filozofii analitycznej i kołu wiedeńskiemu. Różniła się od nich wszakże swoją naturą ściśle metodyczną: chodziło o to, jak uprawiać filozofię, a nie o to, jakie tezy filozoficzne wyznawać. W związku z tym szkoła lwowsko-warszawska nigdy nie miała systematycznie charakteru antymetafizycznego i nigdy nie postulowała ograniczenia filozofii do analizy języka ${ }^{8}$. Podstawowym postulatem szkoły był natomiast naukowy charakter filozofii, w szczególności precyzyjne formułowanie tez i poszukiwanie ich adekwatnego uzasadnienia. Dlatego jedyną tezą filozoficzną niejako z góry wykluczaną w szkole lwowsko-warszawskiej był irracjonalizm (w tym sceptycyzm). Niezwykłe sukcesy szkoły lwowsko-warszawskiej w dwudziestoleciu międzywojennym i jej wpływ na niemal wszystkie dziedziny intelektualnego życia Polski z jednej strony, a metodyczny charakter i wolność od typowych dla ówczesnej filozofii analitycznej i koła wiedeńskiego założeń merytorycznych z drugiej, miały decydujący wpływ na powstanie koła krakowskiego. Program szkoły lwowsko-warszawskiej w oryginalnym ujęciu Twardowskiego jest rekonstruowany zarówno w oparciu o prace Twardowskiego, wspomnienia jego uczniów, jak też na podstawie praktyki filozofowania tej grupy. Godząc się z pewnym uproszczeniem, można ten program ująć w następujących postulatach: (a) filozofia powinna mieć charakter naukowy, a nie światopoglądowy

7 Tamże, 10-11.

8 J. Woleński, How to Speak About History of Analytic Philosophy, w: The Significance of the Lvov-Warsaw School in the European Culture, dz. cyt., 17-18, 22. 
lub literacki, (b) tezy filozoficzne powinny być formułowane w precyzyjnym języku, (c) jedynymi dozwolonymi kryteriami rozstrzygania problemów i uzasadniania twierdzeń filozoficznych powinny być doświadczenie zmysłowe, doświadczenie wewnętrzne i logiczne rozumowanie?.

Uwzględniając pewne zróżnicowanie szkoły lwowsko-warszawskiej pod względem poglądów na naturę filozofii, można ewentualnie doprecyzować tezę (1a). Twardowski i jego najważniejsi uczniowie, dzieląc ocenę zastanej filozofii, ogólny program filozoficzny i zasadniczą postawę metodologiczną, różnili się w poglądach na wiele szczegółów projektowanego gmachu filozofii naukowej ${ }^{10}$. Wszyscy założyciele koła krakowskiego należeli do opcji Jana Łukasiewicza, z którym byli na różne sposoby związani osobiście, który im patronował i który był światopoglądowo bliski myśli katolickiej ${ }^{11}$. Wobec tego, nie unieważniając tezy (1a), można dopowiedzieć, że w programie koła krakowskiego chodziło o

wdrożenie w katolickich instytucjach teologicznych i filozoficznych programu szkoły lwowsko-warszawskiej w wersji Jana Łukasiewicza.(1b)

Poglądy Łukasiewicza w zakresie programu filozoficznego zmieniały się, można wszakże powiedzieć, że pewne tezy lub postawy programowe wyróżniały Łukasiewicza spośród pierwszego pokolenia uczniów Twardowskiego. Wśród tych myślicieli, których można uznać za filary szkoły lwowsko-warszawskiej Łukasiewicz był, po pierwsze, najbardziej otwarty na problematykę typową dla filozofii starożytnej i średniowiecznej, w tym na problemy metafizyczne i teologiczne. Był też - jeśli wyłączyć historyków filozofii - najbardziej obznajomiony z tymi problemami. Nieco inaczej, niż Twardowski, Łukasiewicz co do zasady nie wykluczał możliwości naukowego

9 J. Woleński, Filozoficzna szkoła Iwowsko-warszawska, dz. cyt. 36-40, 310-311.

10 Tamże, 36-40, 52-77.

11 Tkaczyk, dz. cyt. 180-181. 
potraktowania jakiegokolwiek problemu, a nawet dopuszczał w dalszej perspektywie powstanie czyniących zadość wszelkim rygorom naukowym systemów filozoficznych. Po drugie, w pierwszym pokoleniu szkoły Łukasiewicz był najbardziej optymistycznie i maksymalistycznie nastawiony do logiki matematycznej. Miał też w tej dziedzinie wielkie osiągnięcia ${ }^{12}$. Można więc powiedzieć, że Łukasiewicz był maksymalistą zarówno w odniesieniu do przedmiotu, jak w odniesieniu do metod filozofii. Jest ciekawe, że Salamucha akurat dokładnie w ten sposób zdefiniował tomizm ${ }^{13}$.

Postulowana przez założycieli koła krakowskiego reforma teologii i filozofii, uprawianych w instytucjach katolickich, miała mieć charakter metodyczny. Nie postulowano (ani nie wykluczano) zmian $\mathrm{w}$ podejmowanej problematyce ani w treści wykładanych teorii. Według Bocheńskiego ogólny postulat lub cel ostateczny (1) wdrożenia programu szkoły lwowsko-warszawskiej w instytucjach katolickich rozbijał się na cztery nieco bardziej szczegółowe postulaty lub też cele pośrednie koła krakowskiego:

odnowa języka katolickiej filozofii i teologii,

unowocześnienie semiotyki i metodologii,

recepcja logiki matematycznej,

stosowanie metod formalnych.

W wymienionych postulatach z całą wyrazistością odbija się program szkoły lwowsko-warszawskiej i to w jasno określonej wersji jest to, jako się rzekło, odbicie programu Łukasiewicza ${ }^{14}$.

Program koła krakowskiego powstał jako reakcja - a w pewnym stopniu wręcz jako odpowiedź - na splot okoliczności, które założyciele koła uznali za wyzwanie. Okoliczności te można uporządkować w czterech punktach:

12 J. Woleński, Filozoficzna szkoła Iwowsko-warszawska, dz. cyt. 52-57.

13 J. Salamucha, Tomizm jako »philosophia perennis«, w: J. Salamucha, Wiedza i wiara. Wybrane pisma filozoficzne, Lublin 1997, 62-63.

14 J.M. Bocheński, Wspomnienia, Kraków 1994, 123-125. 
esprit de l'époque,

sytuacja w filozofii,

sytuacja w logice,

sytuacja w teologii. (3a)

Splot okoliczności, które układają się w punkty (3), wytworzył sytuację, w której powstanie koła krakowskiego nie było może nieuchronną koniecznością dziejową, ale z pewnością nie było deus ex machina. Powstanie i działalność koła krakowskiego z punktu widzenia jego członków została już szczegółowo przedstawiona ${ }^{15}$, dlatego niniejsza praca pomija te wątki, koncentrując się na milieu, na kulturowych ramach, w których doszło do sformułowania manifestu koła i które w znacznym stopniu ten manifest wyjaśniają.

Opracowania dotyczące koła krakowskiego koncentrują się zwykle na punktach (3b) i (3c). Celem niniejszego tekstu jest przedstawienie genezy koła krakowskiego w możliwie szerokim kontekście. Punkt (3d) wymaga jawi się jako istotny i wymaga docenienia. Wypada też krótko zaznaczyć punkt (3a), który ma znacznie mniejszą wagę niż pozostałe punkty (3), ale przecież nie jest tej wagi całkiem pozbawiony. Dlatego w dalszej części tej pracy, w $§ 3$ zostanie krótko zaznaczony esprit de l'époque powołania do istnienia koła krakowskiego, w $\$ 4$ zostanie omówiona sytuacja w filozofii, w $\$ 5$ sytuacja w logice, a w $\S \S 6$ i 7 możliwie szczegółowo przedstawi się teologiczny kontekst powstania koła krakowskiego.

\section{ESPRIT DE L'ÉPOQUE}

Nie głosząc żadnej wersji determinizmu historii, trzeba zauważyć, że czas, w którym powstało koło krakowskie, sprzyjał tworzeniu śmiałych, maksymalistycznych projektów w niemal wszystkich

15 M. Tkaczyk, dz. cyt.; R. Murawski, Filozofia logiki i matematyki w Kole Krakowskim, Filozofia Nauki 22(2014)2, 21-35; Z. Wolak, Naukowa filozofia koła krakowskiego, Zagadnienia Filozoficzne w Nauce 36(2005), 97-122. 
dziedzinach życia. Dwudziestolecie międzywojenne było epoką élan vital. Po dekadencji dziewiętnastowiecznego fin de siècle pozostało niewiele śladów. Kulturę charakteryzował optymizm, wiara w postęp, odwaga w myśleniu i gotowość do działania, wcale niezłamane doświadczeniem pierwszej wojny światowej. $\mathrm{Na}$ tej żyznej glebie duchowej obficie wschodziły różne - dobre i złe, a nawet te przerażająco złe - ideologie i inne wielkie przedsięwzięcia.

W Polsce ta atmosfera była silniejsza niż gdziekolwiek indziej. Wskrzeszone państwo przypominało gigantyczny plac pudowy, na którym miano wznosić nawet tajemnicze szklane domy ze snu inżyniera Baryki. Za granicę możliwości uznawano tylko granicę marzeń, a siły mierzono na zamiary.

Od chwili swojego powstania II Rzeczpospolita intensywnie organizowała życie naukowe na wszystkich szczeblach. W 1918 roku istniało w Polsce tylko osiem uczelni wyższych: Uniwersytet Jagielloński w Krakowie, Uniwersytet Jana Kazimierza i Politechnika we Lwowie, Uniwersytet, Politechnika, Wyższa Szkoła Handlowa i Szkoła Główna Gospodarstwa Wiejskiego w Warszawie oraz Katolicki Uniwersytet Lubelski w Lublinie. W roku 1924 było ich już siedemnaście, a w latach trzydziestych trzydzieści dwie ${ }^{16}$. Powstawało wiele państwowych i prywatnych przedsięwzięć naukowych. Dość powszechnie wierzono, że trwa budowa mocarstwowej Polski, która przetrwa pokolenia. Obok warszawskiej szkoły matematycznej szkoła lwowsko-warszawska była dość powszechnie zaliczana do mocarstwowych - jak mawiał Bocheński - osiągnięć ówczesnej Polski.

Nie przeceniając klimatu epoki, warto pamiętać, że sprzyja on śmiałym przedsięwzięciom, bywa im mniej więcej obojętny lub do nich zniechęca. Okres międzywojenny w Polsce, zwłaszcza zaś lata trzydzieste, w których szkoła lwowsko-warszawska osiągnęła dojrzałość i zdobyła ogólnoświatową renomę, sprzyjał formułowaniu śmiałych projektów przez polskich filozofów traktujących swoją pracę

16 W. Roszkowski, Najnowsza historia Polski 1914-1945, Warszawa 2003, 125, 379. 
nie tylko jako profesję, ale również jako misję społeczną. Takimi ludźmi byli założyciele koła krakowskiego oraz ich główni mentorzy. Wystarczy wspomnieć, że wedle niektórych przekazów osobiste przeżywanie wolności i niepodległości Polski miało realny wpływ na odrzucenie przez Łukasiewicza deterministycznej - jak sądził - logiki klasycznej i powstanie, preferujących - jego zdaniem - wolność, logik wielowartościowych. Jeżeli założyciele koła krakowskiego wierzyliby, że Historia lub nawet Niebiosa zleciły im - polskim logikom katolickim - misję wielkiej odnowy teologii i że ta misja ma realne szanse powodzenia, to nie wyróżnialiby się przez to specjalnie na tle współczesnych sobie współobywateli, a nawet na tle całej ówczesnej rozgorączkowanej rewolucyjnym duchem Europy.

\section{SYTUACJA W FILOZOFII}

Przełom XIX i XX wieku wyznacza bez wątpienia nowy okres w dziejach filozofii, aczkolwiek może przedwcześnie byłoby wyrokować, czy filozofia współczesna jest nową epoką, podepoką czy może podpodepoką. Odpowiedź na to pytanie dzieli filozofów. Bocheński dopatrywał się tutaj początku wielkiej epoki tego samego poziomu, co starożytność, średniowiecze i nowożytność, nie zaś tego poziomu, co okres szkół hellenistycznych i okres szkół epoki cesarstwa, wczesna scholastyka, XII-XIII wiek i późna scholastyka ani też wiek XVII i XVIII. W wielu publikacjach podkreślał to za pomocą nazewnictwa. Filozofię od XVII do XIX wieku nazywał nowożytną (ang. modern, niem. moderne), a filozofię XX wieku współczesną (ang. contemporary, niem. der Gegenwart). Bocheński kładł nacisk na to, że filozofia współczesna powstaje w ostrej opozycji do zastanej filozofii nowożytnej i pod względem ducha jest bliższa scholastyce.

Trudno byłoby, zapewne, pociągnąć ostrą granicę między tym, co w deklaracjach historycznych Bocheńskiego stanowi wspomnienie jego faktycznej postawy z czasów młodości, a refleksją prowadzoną z perspektywy czasu. Wolno przypuszczać, że w połowie lat 
trzydziestych, kiedy powstawało koło krakowskie, jego założyciele, którzy byli pod wyraźnym wpływem kwitnącej już szkoły lwowsko-warszawskiej, mieli świadomość współtworzenia w filozofii czegoś nowego. Na przełomie lat 1943 i 1944, czyli krótko po zakończeniu działalności koła krakowskiego jako takiego, Bocheński przygotował skrypt $\mathrm{z}$ historii filozofii i na podstawie tego skryptu prowadził wykłady dla polskich nauczycieli przebywających w czasie wojny w Szkocji1 ${ }^{17}$. Wykład kończy się w XIX wieku na niemieckiej filozofii idealistycznej i pozytywizmie. Krótko po wojnie ukazała się obszerna książka Bocheńskiego Europäische Philosophie der Gegenwart ${ }^{18}$, poświęcona filozofii pierwszej połowy XX wieku. Jak pisał pół wieku później, już w tej książce dał w pełni wyraz swojemu przekonaniu o głębokim przewrocie $\mathrm{w}$ filozofii i zerwaniu $\mathrm{z}$ bezpośrednią przeszłością na początku XX wieku' ${ }^{19}$.

W przywołanej pracy z roku 1947 Bocheński rysuje następujący obraz dziejów filozofii. Punktem odniesienia jest dla niego scholastyka. Jako cechy wyróżniające scholastyczną wizję rzeczywistości wymienia:
pluralizm,
personalizm,
organicyzm,
teocentryzm,
metoda analizy logicznej

Punkty (4a)-(4d) wyrażają meritum scholastyki. Pluralizm jest tutaj rozumiany jako założenie realnej o wielości bytów i warstw lub aspektów w bycie, personalizm jako uznanie podstawowej wartości osoby ludzkiej, organicyzm jako organiczna koncepcja rzeczywistości, postrzeganie rzeczywistości na podobieństwo organizmu, a teocentryzm jest to umieszczenie Boga jako stwórcy w centrum rozważań.

\footnotetext{
17 J.M. Bocheński, Zarys historii filozofii, Kraków 1993.

18 J.M. Bocheński, Europäische Philosophie der Gegenwart, Bern 1947.

19 J.M. Bocheński, Zarys historii filozofii, dz. cyt., 217.
} 
Punkt (4e) ma charakter metodologiczny. Charakterystyczną dla scholastyki metodę filozofowania opisuje jako „szczegółową analizę logiczną pojedynczych, wyodrębnionych problemów”.

Filozofia nowożytna, jak twierdzi Bocheński, stanowi zaprzeczenie wszystkich wymienionych cech i charakteryzuje się następującymi cechami:

mechanicyzm,

materializm,

subiektywizm,

odrzucenie logiki,

wielkie systemy filozoficzne

W odniesieniu do meritum filozofii nowożytnej stanowią w tym ujęciu materialistyczny mechanicyzm (postrzeganie rzeczywistości jako jednego mechanizmu $\mathrm{z}$ wykluczeniem pluralizmu, personalizmu i organicyzmu w rozumieniu scholastycznym) i subiektywizm (skoncentrowanie na podmiocie $\mathrm{z}$ wykluczeniem teocentryzmu). W zakresie metody odrzucenie logiki i analizy na rzecz tworzenia wielkich, wszechogarniających systemów filozoficznych ${ }^{20}$.

$\mathrm{Na}$ początku XX wieku w całej kulturze dochodzi do przesilenia o głębi i rozmiarach nie znanych przynajmniej od początków renesansu. Na terenie światopoglądowym widocznym objawem tego przesilenia jest powstanie i rozpowszechnienie trendów, które zrywały z dwoma głównymi elementami światopoglądu nowożytnego: materialistycznym mechanicyzmem i subiektywizmem. Wyraźne są przemiany społeczne, zawirowania ekonomiczne, kontrowersje religijne i przewartościowane w sztuce. $W$ praktycznie wszystkich dziedzinach życia doszło do wzruszenia podstawowych zastanych koncepcji, a trwające wojny pogłębiły rozpad nowożytnego świata. W dziedzinie nauki nastąpiły następujące, różnorako powiązane między sobą zmiany:

20 J.M. Bocheński, Europäische Philosophie der Gegenwart, dz. cyt. § 1A. 
kryzys w podstawach matematyki i fizyki,

rozwój metod matematyczno-logicznych i fenomenologicznych, (6b)

powstanie nowych form irracjonalizmu i metafizyki

Kryzys w podstawach matematyki i fizyki doprowadził do upadku wielu typowych dziewiętnastowiecznych ujęć raz do intensyfikacji myślenia analitycznego, praktycznie równoczesny rozwój metod matematyczno-logicznych i fenomenologicznych otworzyło nowy rozdział pod względem metod filozofowania, a narodziny nowych form witalistycznego irracjonalizmu oraz realistycznej metafizyki wyznacza w filozofii nowy etap z merytorycznego punktu widzenia. Według Bocheńskiego właśnie wymienione zmiany bezpośrednio doprowadziły do głębokiej zmiany w filozofii. Jego zdaniem ten kryzys stanowił ostateczne opuszczenie kurtyny na całą epokę nowożytną ${ }^{21}$.

Filozofia dwudziestowieczna powstała w akcie zerwania $z$ filozofią dziewiętnastowieczną, przed pierwszą wojną światową w formie zaczątkowej, a po tej wojnie w formie dojrzałej. Bocheński dzieli nurty filozoficzne pierwszej połowy dwudziestego wieku osobno ze względu na treść i ze względu na metodę, podkreślając zdumiewającą niezależność tych podziałów. Ze względu na treść wyróżnia empiryzm, idealizm kantowski i idealizm hegeliański, jako transformacje nurtów osiemnastego i dziewiętnastego stulecia, a także filozofię życia, filozofię rzeczy (fenomenologię), egzystencjalizm i nową metafizykę. Jako specyficzne metody filozofowania wyróżnia metodę fenomenologiczną i metodę matematyczno-logiczną, które moga przeplatać się w skomplikowany sposób ${ }^{22}$. W innym miejscu Bocheński pisze o fenomenologii i metodach analitycznych w duchu George'a Edwarda Moore'a ${ }^{23}$. W całej twórczości Bocheńskiego na omawiany temat przebija też przekonanie, że filozofia dwudziestego wieku stanowi dość ostre zerwanie z problematyką teorii poznania,

21 Tamże, § $2 \mathrm{~A}$.

22 Tamże, §4A.

23 J.M. Bocheński, Zarys historii filozofii, dz. cyt., 218. 
czy też krytyki poznania na rzecz problemów przedmiotowych. W późniejszych latach Bocheński dodał do tej charakterystyki jeszcze tezę o odejściu od światopoglądowego charakteru filozofii na rzecz jej charakteru naukowego, w szczególności zarzucenie wielkich systemów na rzecz analizy dokładnie określonych problemów ${ }^{24}$. Bocheński powiedziałby, że filozofia dwudziestowieczna charakteryzuje się przede wszystkim następującymi cechami:

charakter naukowy zamiast charakteru światopoglądowego,

nastawienie przedmiotowe zamiast nastawienia podmiotowego, (7b)

powrót do logiki,

powrót do metody logicznej analizy wąskich problemów rozwój metody fenomenologicznej

Byłoby może przesadą mówić tutaj o powrocie do scholastyki, ale widać niewątpliwie mocne nawiązanie do myśli scholastycznej w opozycji do myśli nowożytnej. Być może, godząc się na pewną niedokładność, można by odczytać naszkicowany przez Bocheńskiego obraz filozofii dwudziestowiecznej jako powrót - na nowym poziomie - do scholastyki, ale bez Pana Boga. Charakterystyka (7) filozofii współczesnej wyraźnie przypomina akceptowany przez Bocheńskiego program szkoły lwowsko-warszawskiej.

Nie ma tutaj miejsca na dyskusję o adekwatności zreferowanego ujęcia. Najważniejsze jest, że Bocheński zdaje sprawę ze stanu świadomości znacznej części swojego pokolenia, w tym środowiska, z którego wyłoniło się koło krakowskie: dawna filozofia skończyła się, powstało coś zupełnie nowego i przeciwstawnego względem poprzedniego okresu.

Widać też, że w rozumieniu Bocheńskiego nowe czasy w filozofii zostały wyznaczone wspólnie przez fenomenologię Edmunda Husserla i przez filozofię analityczną ze szczególnym uwzględnieniem szeroko pojmowanej logiki. Metoda fenomenologiczna powstała pod hasłem „z powrotem do rzeczy samych” a początek 
filozofii analitycznej w Oxfordzie jest wyznaczony przez dosłownie pojmowany bunt George'a Edwarda Moore’a i Bertranda Russella przeciwko reprezentantom romantycznego idealizmu. Stąd prawdopodobnie bierze się u Bocheńskiego świadomość nie tylko ważnej nowości, ale ostrego zwrotu w filozofii.

W dwudziestoleciu międzywojennym trzy najważniejsze ośrodki filozofii analitycznej ukształtowały się w Wielkiej Brytanii, najpierw w Oxfordzie, a później również w Cambridge (pewnie dlatego, zwłaszcza wczesna filozofia analityczna, bywa do dzisiaj niezbyt szczęśliwie określana jako filozofia brytyjska i przeciwstawiana filozofii kontynentalnej), w Wiedniu (koło wiedeńskie) i w Polsce (właśnie szkoła lwowsko-warszawska).

Szkoła Twardowskiego, chociaż nie była tworzona z zamysłem rewolucyjnym, stanowiła ważny element nie tylko nowego okresu filozofii, ale wspomnianej atmosfery wykuwania nowej przyszłości w Polsce. Niektóre ze śmiałych marzeń zaczynały się najwidoczniej iścić. Umiejętności i niezłomna wola jednego człowieka, Kazimierza Twardowskiego, ukształtowały autentyczną kulturę naukową najwyższej próby. Jak już wspomniano, w tamtym l'esprit de l'époque czterech zapaleńców mogło rozsądnie planować transformację całej teologii. Skoro plan Twardowskiego zadziałał w tylu dziedzinach, nie było widać powodu, by miał zawieść $\mathrm{w}$ dziedzinie teologii. Wystarczyło więc zrobić z Twardowskim to, co niegdyś Tomasz z Akwinu zrobił z Arystotelesem. Kiedy okaże się, o ile nowa teologia jest lepsza od dotychczasowej, przyjęcie tej nowej teologii przez ogól będzie kwestią czasu. W Polsce okresu interbellum takie rozumowanie mogło wydawać się uprawnione.

\section{SYTUACJA W LOGICE}

Jeżeli ogólny klimat duchowy sprzyjał powstaniu koła krakowskiego, to sytuacja w logice (3c) na początku dwudziestego wieku była sprzyjająca w stopniu zupełnie wyjątkowym. W drugiej połowie wieku 
dziewiętnastego i w początkach dwudziestego powstała logika matematyczna. Została ona zainicjowana przez takich uczonych, jak Augustus De Morgan, George Boole, następnie Ernst Schröder, Giuseppe Peano, a zwłaszcza Charles Sanders Peirce i Gottlob Frege. Bocheński w wielu miejscach podkreśla, że okresie nowożytności logika znajdowała się w stanie zupełnego upadku, a jej odrodzenie stało się prawdziwym przełomem. Pod względem rozmiarów i doniosłości przełom ten można porównać tylko ze stworzeniem logiki przez Arystotelesa, a zdaniem niektórych komentatorów nawet nie.

Logika matematyczna powstała m.in. jako próba przezwyciężenia wspominanego już w $§ 4$ kryzysu w podstawach matematyki. Do tego kryzysu doszło przede wszystkim w związku ze stworzeniem geometrii nieeuklidesowych oraz z wykryciem licznych antynomii i innych paradoksów w różnych działach matematyki, przede wszystkim w rachunku różniczkowym i całkowym oraz $\mathrm{w}$ teorii mnogości. Z jednej strony, stworzenie geometrii nieeuklidesowych dostarczyło teorii, których założenia wydawały się oczywiście fałszywe, ale które same robiły wrażenie poprawnych. $Z$ drugiej strony, $\mathrm{w}$ antynomiach pokazano przykłady dowodów, których założenia robiły wrażenie oczywiście prawdziwych i których wszystkie kroki wydawały się oczywiście prawidłowe, ale które kończyły się dowiedzeniem sprzecznych twierdzeń. Pierwszy raz w dziejach matematyki pytania o to, który dowód jest poprawny, które twierdzenie jest dowodliwe i jak należy rozumieć nawet najprostsze pojęcia, okazały się wysoce problematyczne, a proste odpowiedzi, które uchodziły za oczywiste, bezpodstawne. Mówiono nawet dramatycznie, że w analizie matematycznej niczego jeszcze nie udowodniono. Jak zauważa Bocheński, wymienione trudności zwróciły uwagę uczonych na takie zagadnienia podstawowe, jak

wykrywanie i usprawiedliwienie założeń teorii,

dokładna analiza nawet pozornie najprostszych pojęć,

zasady konstruowania i własności teorii aksjomatycznych 
Logika matematyczna objawiła swoją wielką skuteczność w podstawach matematyki, ale początkowo jej znajomość i uznanie dla niej ograniczało się do społeczności matematyków ${ }^{25}$.

$Z$ punktu widzenia koła krakowskiego okolicznością równie ważną, jak powstanie nowej logiki, była jej recepcja w środowisku filozoficznym. Przez pierwsze pięćdziesiąt lat jej istnienia logika matematyczna pozostawała praktycznie nieznana wśród filozofów. Wśród wymienionych twórców tej logiki dopiero Peirce i Frege podejmowali zagadnienia filozoficzne, ale byli oni naukowymi samotnikami. Drzwi filozofii otworzyły się dla logiki matematycznej dopiero w roku 1900, w którym Peano zapoznał z jej podstawami Bertranda Russella. Chociaż poprzedzone doniosłymi, ale nieznanymi, dziełami Peirce'a i Fregego, dopiero praca Russella Principles of Mathematics z 1903 roku i wielkie dzieło Principia Mathematica Alfreda N. Whiteheada i Russella z lat 1910-1913 zapoczątkowały recepcję logiki matematycznej wśród filozofów (w pierwszym rzędzie wśród filozofów znających język angielski). Wielu filozofów zdało sobie sprawę, że mimo matematycznej genezy logika matematyczna stanowi narzędzie całkiem uniwersalne. Jest też logiką w tym samym sensie, co logika tradycyjna, ale jest dużo potężniejsza, otwiera więc nowe, niewyobrażalne dotąd możliwości stosowania. Zdaniem Bocheńskiego recepcja logiki matematycznej w filozofii wpłynęła zarówno na metodę, jak na treść, rozważań filozoficznych, ponieważ okazała się najlepszym narzędziem analizy pojęć, wnioskowań i teorii,

znalazła zastosowanie w dziedzinach, które

nie poddają się metodom matematycznym,

jej stosowanie doprowadziło do ożywienia wielu

klasycznych problemów filozoficznych

Wśród problemów, o których jest mowa w punkcie (9c) Bocheński wymienia problem uniwersaliów, zagadnienia semiotyki i gramatyki

25 J.M. Bocheński, Europäische Philosophie der Gegenwart, dz. cyt. § 2D. 
uniwersalnej, problem prawdziwości i usprawiedliwienia aksjomatów i podobne ${ }^{26}$.

W pierwszych dekadach dwudziestego wieku powstały logiki nieklasyczne, otwierając przed logiką, jak napisał Rudolf Carnap, „nieograniczone morze możliwości”. Co prawda, pojawiły się twierdzenia limitacyjne, ale były one traktowane raczej jako znak potęgi nowych metod formalnych niż ich ograniczenia. W tym samym czasie głębokim przemianom ulegała fizyka. Można było odnosić wrażenie, że nowa logika w krótkim czasie zrewolucjonizuje całą wiedzę, być może, doprowadzi nawet do ziszczenia marzeń Gottfrieda Wilhelma Leibniza o uniwersalnym algorytmie rozwiązywania wszelkich problemów.

Dodatkowo właśnie wtedy Warszawa stała się jednym z głównych - a przez pewien czas zapewne głównym - ośrodkiem badań logicznych na świecie. Łukasiewicz, który w wielkim stopniu współtworzył sukces nowej logiki, a nie koncentrował się na jej ograniczeniach, był zarazem teistą i znał historię myśli katolickiej, zwłaszcza metafizykę. Miał też rzadki talent do odkrywania nowych problemów badawczych. Na przykład, już w 1926 roku, na dwa lata przed publikacją aksjomatycznej wersji logiki kwantyfikatorów przez Davida Hilberta i Wilhelma Ackermanna, postawił problem dedukcji naturalnej, inspirując do poszukiwań swojego ucznia, Stanisława Jaśkowskiego. Byłoby wręcz dziwne i wymagałoby wyjaśnienia, gdyby, mając wśród uczniów duchownych i innych zaangażowanych intelektualistów katolickich, nie zachęcił ich do rekonstrukcji metafizyki i teologii zgodnie z kanonami logiki matematycznej. Nie jest niczym niezwykłym to, że profesor sugeruje seminarzyście, który ukończył więcej niż jeden kierunek studiów, podjęcie pracy interdyscyplinarnej. Na przykład profesor logiki proponuje doktorantowi, który jest absolwentem psychologii, pracę z pogranicza logiki i psychologii. 
Jest więcej niż prawdopodobne, że Łukasiewicz odegrał podobną rolę w powstaniu koła krakowskiego.

Widać, że w dziedzinie logiki splotły się trzy ważne okoliczności: (a) powstanie i niezwykły rozwój logiki matematycznej, (b) recepcja i znaczące sukcesy nowej logiki w dziedzinie filozofii, (c) bardzo silna pozycja logiki polskiej. Ten splot okoliczności przyczynił się walnie do sformułowania programu koła krakowskiego. Można by nawet uzupełnić tę listę o czwartą okoliczność (d) osobiste związki Łukasiewicza z czołowymi myślicielami kręgu Kościoła katolickiego. Nie jest to zapewne okoliczność równie doniosła, jak trzy pierwsze, ale w znacznym stopniu przyczynia się do wyjaśnienia i naświetlenia wystąpienia grupy logików katolickich ${ }^{27}$.

\section{TEOLOGICZNY MANIFEST KOŁA KRAKOWSKIEGO}

Starając się zrozumieć koło krakowskie, nie wolno zapominać, że było ono w najgłębszej istocie ruchem teologicznym wewnątrz Kościoła katolickiego. W katolickim ujęciu filozofia jest integralną częścią szeroko pojmowanej teologii, stąd bierze się nieustające zainteresowanie i zaangażowanie filozoficzne świata katolickiego. Twórcy koła krakowskiego uważali, że udzielają odpowiedzi na potrzeby współczesnej im teologii, dlatego bez zrozumienia ówczesnej sytuacji teologicznej obraz koła krakowskiego nie mógłby być pełny.

Szczę́liwie w odniesieniu do kontekstu teologicznego dysponujemy wyraźnym i szczegółowym manifestem koła krakowskiego w postaci odczytów wygłoszonych podczas programowej konferencji koła w Krakowie, we wrześniu 1936 roku, w obecności 32 oficjalnie zarejestrowanych reprezentantów katolickich ośrodków naukowych i seminariów duchownych. Prelegentami byli: Łukasiewicz (Wobronie

27 J. Woleński, Filozoficzna szkoła Iwowsko-warszawska, dz. cyt.; J. Woleński, Józef M. Bocheński i Koło Krakowskie, dz. cyt.; M. Tkaczyk, Cracow Circle. Theology in the Lvov-Warsaw School, dz. cyt. 
logistyki), Bocheński (Ścisłość w tradycji myśli katolickiej), Salamucha (Porównanie scholastycznych i logistycznych narzędzi logicznych) i Drewnowski (Neoscholastyka wobec nowoczesnych wymagań nauki), a gospodarzem Konstanty Michalski. Wszystkie odczyty i protokół $\mathrm{z}$ dyskusji opublikowano $\mathrm{w}$ tomie pod redakcją Salamuchy ${ }^{28}$. Przebieg i skutki tej konferencji omówiono gdzie indziej29, dlatego tutaj wystarczy ograniczyć się do kilku podstawowych uwag.

W wygłoszonych odczytach sformułowano i broniono tezy, że teologia katolicka jest programowo wiedzą naukową, to znaczy, do istoty teologii katolickiej należy spełnianie wszelkich kryteriów wiedzy naukowej, akceptowanych w danym okresie. Dawni myśliciele katoliccy, zwłaszcza scholastycy, byli wiodącymi uczonymi swoich czasów. Gdyby więc uprawiali teologię w wieku dwudziestym, stosowaliby się do wymogów naukowych wieku dwudziestego, a nie trzynastego. Kanonu nauki w dwudziestym wieku dostarcza zaś logika matematyczna. W największym skrócie pogląd ten ujął Drewnowski: „Summa teologiczna była, na owe czasy, szczytem ścisłości naukowej; dziś dzieła czołowych przedstawicieli odrodzonej scholastyki są, w wielu razach, tylko pięknymi essayami z pogranicza nauki i sztuki"30.

Streszczona tu idea została najszerzej wyłożona przez Bocheńskiego. Myśl katolicka zawsze wedle własnej świadomości miała być częścią nauki, dlatego dążyła do używania metod naukowych i to nie jakichkolwiek, ale najlepszych metod dostępnych nauce danego okresu $^{31}$. Z tego punktu widzenia Bocheński wyznacza w historii

28 Tradycja myśli katolickiej a ścisłość, red. J. Salamucha, Kraków 1937.

29 J. Woleński, Józef M. Bocheński i Koło Krakowskie, dz. cyt.; M. Tkaczyk, Cracow Circle. Theology in the Lvov-Warsaw School, dz. cyt.

30 J.F. Drewnowski, Neoscholastyka wobec nowoczesnych wymagań nauki, w: Myśl katolicka wobec logiki współczesnej, dz. cyt., 51.

31 J.M. Bocheński, Tradycja myśli katolickiej a ścisłość, w: Myśl katolicka wobec logiki współczesnej, dz. cyt., 30, 34. 
teologii trzy punkty graniczne, określające przemiany metodologiczne tej dyscypliny ${ }^{32}$ :

założenie szkoły katechetycznej w Aleksandrii,

powstanie metody scholastycznej,

Encyklika Eterni Patris Leona XIII z 1879 r. ${ }^{33}$

Od razu widać, że Bocheński posłużył się tutaj synekdochą pars pro toto. Przywołuje bowiem trzy okresy rozwoju teologii: patrystykę, czyli teologię Ojców Kościoła, scholastykę i neoscholastykę, reprezentowane kolejno przez szkołę aleksandryjską, opracowanie metody scholastycznej ze szczególnym uwzględnieniem Tomasza z Akwinu oraz encyklikę Eterni Patris, która reprezentuje cały ruch odnowy scholastyki na przełomie wieków XIX i XX. Cel tego zabiegu stanie się wkrótce jasny. Dodajmy, że manifest koła krakowskiego jest tutaj wyraźnie wiązany z ostatnią cezurą, mianowicie z ogłoszeniem encykliki Eterni Patris. Bocheński wyraźnie stara się zaprezentować koło krakowskie nie tylko - choć, rzecz jasna, przede wszystkim - jako pełnoprawne stadium rozwoju jednolitej tradycji myślowej katolicyzmu, ale w szczególności jako składnik ruchu, którego symbolem lub etykietą jest wymieniona encyklika.

Bocheński koncentruje się najpierw na epoce Ojców Kościoła. Pomijając Justyna Męczennika, który chyba jako pierwszy głosił, że doktryna chrześcijańska jest po prostu prawdziwą filozofią, Bocheński przywołuje działalność szkoły katechetycznej w Aleksandrii. Szkoła ta jest przedstawiona jako miejsce, w którym zrodziła się idea, że teologia może i powinna być nauką w pełni znaczenia tego terminu: „sformułowano tam [w szkole aleksandryjskiej] po raz pierwszy zasadę, że możliwa jest gnosis o wierze (...). Nie była ta gnoza nawet $\mathrm{w}$ przybliżeniu nauką ścisłą $\mathrm{w}$ dzisiejszym tego słowa znaczeniu, ale bez względu na przeprowadzenie, nią być chciała; myśliciele szkoły aleksandryjskiej wypowiedzieli twierdzenie, że

32 Tamże, 30-34.

33 Leon XIII, AEterni Patris, Acta Leonis Papce, R 1882, t. 1, 225-284. 
do Boga należy się nie tylko modlić, ale że trzeba o Nim i o Jego tajemnicach myśleć ściśle, na sposób filozofów, z użyciem analizy semantycznej prawd wiary i innych metod racjonalnych" 34 . Warto zauważyć wyraźne odróżnienie pozytywnej tezy programowej, to jest projektu teologii, która byłaby nauką nauki, od negatywnej tezy faktycznej: teologii uprawianej w szkole katechetycznej nie da się uznać za naukę. Widać w tym cel Bocheńskiego. Chodzi o uzasadnienie tezy, że prawdziwym naśladowcą Ojców Kościoła jest nie ten, kto uprawia teologię w sposób charakterystyczny dla starożytności, ale ten, kto uprawia teologię w sposób charakterystyczny dla czasów współczesnych. Innymi słowy, dobrym naśladowcą Ojców Kościoła jest nie ten, kto uprawia teologię w taki sposób, w jaki uprawiali ją Ojcowie Kościoła, ale ten, kto uprawia teologię w sposób, w jaki uprawialiby ją Ojcowie Kościoła, gdyby żyli współcześnie. Trudno nie dopowiedzieć w myślach milcząco sugerowanej tezy: współczesną szkołą aleksandryjską jest koło krakowskie.

Bocheński stara się pokazać, że idea zrodzona w szkole aleksandryjskiej stała się standardem myśli katolickiej. Pokazują to (a) wielkie spory trynitarne i chrystologiczne, które kończyły się definicjami dogmatycznymi kolejnych soborów powszechnych, czyli analizą pojęciową, (b) odrzucenie tendencji irracjonalistycznej, reprezentowanej przez dzieła Pseudo-Dionizego Areopagity oraz (c) powszechne włączanie kursu ówczesnej logiki do starożytnych syntez teologicznych.

Wielkie spory trynitarne, w szczególności działalność Atanazego Wielkiego potwierdzają, że była to świadomość i tendencja całego Kościoła, który w ogniu walki doktrynalnej uciekał się do analizy znaczenia słów, definiowania, formułowania twierdzeń, konstruowania dowodów i systemów ${ }^{35}$.

Drugim wielkim polem aktywności twórców metodologii teologicznej miało być przezwyciężenie wpływu na teologię idei

34 Tamże, 30.

35 Tamże. 
Pseudo-Dionizego Areopagity. Według Bocheńskiego katolicyzm jako całość oparł się tej pokusie, aczkolwiek wypada zaznaczyć, że jak zauważa Joseph Pieper - wpływ teologii dionizyjskiej (Corpus Dionysiacum) na Wschodzie i na Zachodzie chrześcijaństwa był długotrwały i ogromny ${ }^{36}$.

Po trzecie, Bocheński podkreśla, że w patrystycznych wykładach teologii logika stanowiła część integralną, np. u Grzegorza z Nazjanzu, Izydora z Sewilli i Jana z Damaszku. Teologia była więc pojmowana jako dziedzina wiedzy, a nie dziedzina literatury pięknej37.

Drugą cezurą, którą wymienia Bocheński, jest powstanie metody scholastycznej. W referowanym odczycie tworzenie tej metody zaczyna się już u Ojców Kościoła, ale wraz z działalnością Boecjusza jest to już świadome i zdeterminowane, chociaż stopniowe, powolne i mozolne, dążenie do określonego celu. Najważniejszymi postaciami na tej drodze byli Abelard i Albert Wielki. Bocheński odnotowuje przy tym opór Bernarda z Clairvaux i Piotra Damianiego, którzy w jego wizji pełnią funkcję bohaterów negatywnych podobnie, jak Pseudo-Dionizy w starożytności. Za przełomowy punkt w procesie tworzenia metody scholastycznej uważa recepcję dzieł Arystotelesa i relatywizację teorii do założeń w Summie teologii 1.1.2. Jest zatem jasne, że metoda scholastyczna osiąga pełną dojrzałość, wzorcową postać i szczytowe osiągnięcia u Tomasza z Akwinu ${ }^{38}$.

Bocheński chwali teologów średniowiecznych za to, że myśl wypracowaną wspólnym wysiłkiem pokoleń powszechnie przyjęli i wdrożyli: „Następcy Doktora Powszechnego kontynuowali jego dzieło, kładąc coraz większy nacisk na logikę formalną, bez której sobie ani filozofii, ani teologii, nie wyobrażali. Wytworzyli to, co nazywamy metodą scholastyczną, a co powinno być nazywane po

36 J. Pieper, Scholastyka. Postacie i zagadnienia filozofii średniowiecznej, Warszawa 1963, 40-45.

37 J.M. Bocheński, Tradycja myśli katolickiej a ścisłość, dz. cyt. 31.

38 J.M. Bocheński, Tradycja myśli katolickiej a ścisłość, dz. cyt., 31-32; tenże, Koło Krakowskie, Kwartalnik Filozoficzny 23(1995)1, s. 135. 
prostu poprawną metodą naukową: według nich należy najpierw jasno i niedwuznacznie definiować użyte słowa i zwroty, następnie wykładać swoje założenia, wreszcie dowodzić tezy osobno i wyraźnie wygłoszonej w jasnym sformułowaniu, używając $\mathrm{w}$ dowodzie sprawnych dyrektyw (...). Metoda scholastyczna to nic innego, tylko naszkicowana powyżej metoda ścisłego mówienia. Całe średniowiecze od XIII wieku używało wyłącznie tej metody w nauce"39. Na podkreślenie w tej części wywodów Bocheńskiego zasługuje utożsamienie metody scholastycznej z ,poprawną metodą naukową" oraz $\mathrm{z}$ „metodą ścisłego mówienia”. $\mathrm{Z}$ kolei dostarczony opis tej metody wskazuje bardzo wyraźnie na utożsamienie jej z jakąś wersją metody aksjomatycznej, zapewne z wersją raczej luźną, ale jednak z metodą aksjomatyczną. $Z$ przytaczanych wypowiedzi Bocheńskiego można by wynieść wrażenie, że od czasów patrystycznych do Tomasza z Akwinu teologowie opracowywali metodę aksjomatyczną, która jest identyczna z metodą naukową tout court i metodą ścisłego mówienia. Ta nieco przesadzona wizja nie jest jednak pozbawiona wszelkich podstaw. Teologowie, co prawda, nie stworzyli metody aksjomatycznej, ale wytrwale, od starożytności do średniowiecza, przez pokolenia, uczyli się wdrażać pewną sztukę myślenia, mówienia i pisania. Sztuki tej nie da się może utożsamić z metodą aksjomatyczną, ale jest to, bez wątpienia, jakaś sztuka budowania teorii w jak najbardziej właściwym sensie terminu „teoria”. Nieco przerysowany obraz został nakreślony przez Bocheńskiego we wspominanym już celu: jak najbardziej zbliżyć klasyczną teologię, w tym wypadku Tomasza z Akwinu i całą scholastykę, do współczesnej logiki.

Trudno nie zauważyć przy tej okazji, że metoda scholastyczna w ujęciu Bocheńskiego nie różni się prawie niczym od programu (1) szkoły lwowsko-warszawskiej. Od poglądu (1a) Twardowskiego różni się tylko tym, że nie wyklucza wyraźnie zagadnień światopoglądowych, a od poglądu (1b) Łukasiewicza tym, że nie podkreśla

39 J.M. Bocheński, Tradycja myśli katolickiej a ścisłość, dz. cyt., 32. 
doniosłości logiki matematycznej. Podobieństwa akceptowanego przez Bocheńskiego programu filozoficznego, jego ujęcia metody scholastycznej i jego opisu (7) filozofii współczesnej są uderzające.

Trzecim kamieniem milowym w wywodzie Bocheńskiego jest ogłoszenie w 1879 r. encykliki Eterni Patris Papieża Leona XIII. Wedle słów Bocheńskiego było ono związane z tym, że wśród teologów katolickich, pod wpływem romantyzmu, zrodziła się tendencja do pójścia drogą literatury pięknej, a nie nauki. Autorytet kościelny wystąpił tutaj jednoznacznie na rzecz tradycji, to znaczy w szczególności na rzecz metody naukowej, czyli - jak pamiętamy - metody scholastycznej, przesądzając sprawę doktrynalnie ${ }^{40}$.

Jak wspomniano ta ostatnia cezura, rozważana przez Bocheńskiego, wydaje się w jego wywodzie najważniejsza, ponieważ koło krakowskie chce być widziane jako uczestnik ruchu neoscholastycznego, reprezentowanego przez encyklikę Leona XIII, a wręcz jako najwierniejszy wyraziciel tego ruchu. Może więc dziwić, że właśnie ten etap rozwoju doktryny został potraktowany bardziej skrótowo niż poprzednie. Aby dać pełne zrozumienie manifestu koła krakowskiego, obraz ten powinien zostać uzupełniony (wybiórczym) zarysem ówczesnej sytuacji teologicznej.

\section{SYTUACJA W TEOLOGII}

Należy zdać sobie sprawę z tego, że wystąpienie Leona XIII było częścią szeroko zakrojonej akcji Papiestwa w ramach kryzysu modernistycznego. Encyklika Aterni Patris była składnikiem antymodernistycznej akcji Rzymu.

Plinio Corrêa de Oliveira zauważa, że kryzys średniowiecznego świata chrześcijańskiego zaczął się prawie bezpośrednio po największych osiągnięciach myśli scholastycznej, to jest w XIV wieku.

40 J.M. Bocheński, Tradycja myśli katolickiej a ścisłość, dz. cyt., 33-34. Por. Salamucha, Tomizm jako »philosophia perennis«, dz. cyt. 
Początkowo był to kryzys obyczajowy, który z czasem doprowadził do podmycia doktrynalnych fundamentów ówczesnej kultury. W tych okolicznościach miały miejsce dwie wielkie rewolucje: w XVI i w XVIII wieku. Pierwszą rewolucję wyznacza humanizm i reformacja, a drugą oświecenie i rewolucja francuska ${ }^{41}$. Na szeroki nurt modernizmu składają się skutki tych procesów wymierzone w myśl katolicką lub przyswojone przez nią.

O kontrowersji modernistycznej pisano po raz pierwszy w XVIII wieku, ale systematyczna reakcja katolicka na modernizm zaczyna się w wieku XIX. Termin 'modernizm' ma rodzinę znaczeń. W XIX wieku do tej rodziny pojęć weszły między innymi: (a) próby kompromisowego uzgodnienia, a więc częściowej recepcji, idei oświecenia, zwłaszcza rewolucji francuskiej i ówczesnej wersji demokracji, podejmowane przez myślicieli katolickich, (b) wprowadzanie do katolicyzmu poglądów i tendencji protestanckich, humanistycznych i liberalnych, pojawiających się w kręgach kultury świeckiej, ze szczególnym uwzględnieniem sekularyzmu, liberalizmu i nowożytnego racjonalizmu, (c) nieograniczona wiara w nowożytne nauki, czyli próba inkorporowania do teologii jakiejś postaci scjentyzmu, (d) łączenie teologii katolickiej z idealistyczną filozofią niemiecką $\mathrm{w}$ wersji kantowskiej lub hegeliańskiej i z neoprotestancką religią uczucia, (e) recepcja historyczno-krytycznej egzegezy biblijnej, (f) ponadwyznaniowe dążenia reformistyczne w religii, w szczególności indyferentyzm i pluralizm ${ }^{42}$.

Jak widać, pojęcie modernizmu nie jest całkiem ostre. Pewnie dlatego w opracowaniach trudno jest znaleźć zadowalającą definicję. Pojęcie modernizmu jest często kształtowane prawie wyłącznie ostensywnie (przez wskazanie modernistów). Wydaje się jednak, że przy całej jego wieloznaczności termin 'modernizm' ma jednak dość dobrze określoną strukturę, typową dla terminów o rodzinie

41 P. Corrêa de Oliveira, Rewolucja i kontrrewolucja, Kraków 2017, 27-30, 127.

42 C. Arnold, Mała historia modernizmu, Kraków 2009, 10-13. 
znaczeń. Rekonstrukcja pojęcia modernizmu powinna uwzględniać tę strukturę. Modernizm jest to więc bez wątpienia prąd teologiczny, filozoficzny i polityczny (jak pisano: herezja w religii, rewolucja w polityce, fałsz w filozofii). W punkcie wyjścia rekonstrukcji rodziny pojęć modernizmu należy przyjąć założenie, że istnieją idee, tezy, teorie wzajemnie wrogie lub przynajmniej obce (na przykład dlatego, że zostały stworzone lub przyswojone przez wrogie grupy). Nie ma tutaj potrzeby szczególowego analizowania tej sprawy. Wystarczy przyjąć, że prototypami nurtów antagonistycznych względem katolicyzmu są protestantyzm, oświecenie, rewolucja. Inne nurty są dołączane do takiej listy przez analogię. Powinno być przy tym jasne, że zakres definiowanego w ten sposób terminu zmienia się w zależności od tego, jak rygorystycznie pojmowana jest obcość lub wrogość między ideami. Teza lub teoria jest w prezentowanym ujęciu modernistyczna, jeśli wymaga lub dopuszcza godzenie katolicyzmu $\mathrm{z}$ jakimś nurtem antagonistycznym $\mathrm{w}$ drodze kompromisu, czyli z uwzględnieniem częściowej recepcji w katolicyzmie nurtu uznanego za antagonistyczny. Pożyczając sformułowanie od św. Augustyna, można byłoby chyba powiedzieć, że modernizm polega na wpuszczaniu przedstawicieli Państwa Ziemskiego do Państwa Bożego.

Rzym reagował na modernizm pośrednio właściwie już od kongresu wiedeńskiego 1815 roku, intensywnie propagując rozwój neoscholastyki, zwłaszcza neotomizmu. Pierwszą wypowiedzią doktrynalną w tej materii był Syllabus Piusa IX z 1864 roku, zestawiający osiemdziesiąt błędów teologicznych charakterystycznych dla tego czasu. Mocniej wystąpił Pius X: w roku 1907 dekretem Lamentabili Świętego Oficjum Inkwizycji Rzymskiej i Powszechnej, potępiającym sześćdziesiąt pięć tez i roztaczającym szczególną kontrolę nad egzegezą Pisma Świętego, a zwłaszcza słynną encykliką Pascendi dominici gregis; następnie w roku 1910 listem motu proprio Sacrorum Antistitum, nakładającym na wszystkich duchownych oraz świeckich 
pełniących funkcje kościelne obowiązek składania specjalnej przysięgi antymodernistycznej ${ }^{43}$.

W tym kontekście ukazują się papieskie zarządzenia, dotyczące neoscholastyki. Jak wspomniano, konsolidacja i zorganizowany rozwój studiów neoscholastycznych, które od średniowiecza nigdy nie zostały całkiem zarzucone, trwa przynajmniej od kongresu wiedeńskiego. W roku 1879 słynna i wielokrotnie już przywoływana encyklika Leona XIII Eterni Patris podsumowuje niejako ten intelektualny rekonesans, ustanawiając neoscholastykę jako naukową normę katolicyzmu. Odzwierciedleniem tego stanowiska jest kanon 1366 \$2 Kodeksu prawa kanonicznego z roku 1917: „Jest obowiązkowe, aby profesorowie nauczali filozofii racjonalnej i teologii, i kształcili swych wychowanków w tych naukach wedle metody, nauki i zasad Doktora Anielskiego i tego się święcie trzymali"44. Czas krystalizacji poglądów Rzymu na teologię i filozofię kończy w roku 1923 Pius XI encykliką Studiorum ducem, zawierającą słynne wezwanie: idźcie do Tomasza! (ite ad Thomam!). Pojawia się ono w następującym kontekście: „Jak niegdyś Egipcjanom w chwili strasznego głodu powiedziano: idźcie do Józefa, aby on udzielił zapasów zboża do wyżywienia ciała, tak i dziś tym wszystkim, którzy łakną prawdy, My mówimy idźcie do Tomasza, a on udzieli im pokarmu zdrowej nauki, którego posiada w obfitości na wieczny żywot ich dusz. Pokarm ten jest gotowy i dostępny dla wszystkich, jak to już było zeznane pod przysięgą w ciągu procesu kanonizacyjnego, który miał zaliczyć Tomasza do grona świętych: »Jasna i przejrzysta nauka tego Doktora dzięki swej zwięzłej, jasnej i dostępnej metodzie, natchnęła wielu doktorów z duchowieństwa zakonnego i świeckiego (...) nawet ludzie świeccy i osoby mniej wykształcone pragną posiadać jego dzieła«. Co się tedy Nas tyczy, pragniemy, aby w szczególności ci wszyscy, którzy mają sobie polecone nauczanie głównych przedmiotów w zakładach

43 Tamże, 83-115.

44 Codex iuris canonici, Romae 1917, kan. 1366 §2. 
naukowych wychowujących młodzież kościelną wzięli poważnie pod uwagę i wiernie zachowywali to wszystko, co w tej sprawie nakazali Nasi poprzednicy Leon XIII i Pius X, jak niemniej i to, co My Sami zarządziliśmy zeszłego roku. Niech będą oni przekonani, że dopiero wtedy zadośćuczynią swym zadaniom i Naszym oczekiwaniom odpowiedzą, gdy, pokochawszy Doktora z Akwinu przez długie i pilne zgłębianie jego dzieł, potrafią przelać w swych uczniów, którym go wykładają, ten sam zapał i uczynić ich przez to zdolnymi, aby podobne zamiłowanie w innych wzbudzali" 45 .

W powstałej sytuacji myśliciele katoliccy mogli obrać jedną z trzech dróg: (a) zignorować akcję antymodernistyczną, ryzykując konfrontację z Rzymem, (b) stać się literalnymi tomistami, ograniczając filozofię i teologię do pewnego systemu filozoficznego określanego jako tomizm na zasadzie iurare in verba magistri, (c) poszukiwać drogi pośredniej, interpretując neoscholastykę jako styl (metodę?) filozofowania, punkt odniesienia lub w jeszcze inny sposób, czyniąc ją szkołą filozoficzną lub teologiczną otwartą na rozwój (a nie jako mniej lub bardziej zamknięty zestaw tez).

Pierwszym filozofem, który świadomie i systematycznie obrał tę trzecią drogę, był Desiré Mercier, twórca tomizmu lowańskiego. Zainicjował on, z jednej strony, dogłębne studia historyczne nad tekstami Tomasza z Akwinu, odróżniając jego teksty od systemów szkół tomistycznych, oraz, z drugiej strony, studia z zakresu nauk przyrodniczych i psychologii empirycznej, a także współczesnej filozofii nauki, zmierzające do ich recepcji w ramach tomizmu na wzór średniowiecznej recepcji Arystotelesa. Założyciele koła krakowskiego widzieli siebie właśnie w tym nurcie teologii katolickiej: „W szeregu neoscholastyków (...) Mercier był pierwszym, który jasno zrozumiał, że nawrót do tomizmu musi być zarazem aktualizacją tomizmu; zadanie to podjął nie tylko sam, bo narzucił je zorganizowanej przez

45 Pius XI, Studiorum ducem, Acta Apostolicae Sedis, vol. 15(1923)7, s. 309-326. 
siebie szkole. Olbrzymią zasługą Merciera i jego szkoły jest wyraźne wykreślenie planu pracy"46.

Koło krakowskie miało pracować w tym samym nurcie, ale w kontekście logiki i metodologii nauk, a nie nauk przyrodniczych. Dlatego jego założyciele kładli nacisk na problemy metodologiczne tomizmu. Większość neoscholastyków koncentrowała się na meritum aktualizowanego tomizmu, uznając zdrowy rozsądek za trzon metody. Stąd właśnie wzięła się w kole krakowskim ostra krytyka zdrowego rozsądku jako instancji filozoficznej. Odnowiony tomizm, argumentowano, jeśli ma być przedsięwzięciem poważnym, nie może być filozofią zdrowego rozsądku. Potrzebuje prawdziwej metodyki naukowej, której dostarczyć może tylko współczesna logika ${ }^{47}$.

Dopiero w zarysowanym kontekście projekt koła krakowskiego staje się zrozumiały. Założyciele koła postulowali dogłębną reformę, aktualizację studiów katolickich. Taka idea mogła być postrzegana bądź jako powtórzenie dzieła Tomasza z Akwinu, który zaktualizował teologię w kontekście myśli Arystotelesa, bądź jako kolejna odsłona modernistycznej herezji, próba zakażenia teologii wirusem obcej filozofii (znanej wówczas w kręgach kościelnych jako logistyka i kojarzonej z neopozytywistyzmem koła wiedeńskiego). Bocheński i Salamucha, którzy byli duchownymi, w różnym czasie byli oficjalnie podejrzewani o modernistyczną herezję, w szczególności w formie pozytywistycznej. Dlatego założyciele koła krakowskiego odwołali się do autorytetu Eukasiewicza i Michalskiego, a także włożyli wiele wysiłku w przedstawienie swojego projektu jako nieodzownej części neoscholastyki. Starali się pokazać, że proponują dokładnie to, co zrobiłby Tomasz z Akwinu, gdyby przyszło mu działać w początkach dwudziestego wieku.

46 J. Salamucha, Tomizm jako »philosophia perennis«, dz. cyt. 59.

47 J. Salamucha, O naukowq metafizykę, w: J. Salamucha, Wiedza i wiara. Wybrane pisma filozoficzne, dz. cyt.; tenże, Tomizm jako »philosophia perennis«, dz. cyt.; J.F. Drewnowski, Neoscholastyka wobec nowoczesnych wymagań nauki, dz. cyt. 
W tym celu musieli odpowiedzieć na trudne pytanie, czym różnią się recepcja arystotelizmu w teologii Tomasza z Akwinu i recepcja reformacji lub oświecenia w teologii modernistów. Założyciele koła krakowskiego zaproponowali tezę, że Tomasz przejął od Arystotelesa język i metodę, czyli standardy naukowe, a nie doktrynę, inaczej, niż moderniści, którzy wprowadzali do korpusu teologii obce lub wrogie treści.

Przyjmując zaproponowaną perspektywę, można zrozumieć, dlaczego założyciele koła krakowskiego proponowali metodologiczną charakterystykę i metodologiczną odnowę teologii. Robili to nie tylko dlatego, że sami interesowali się logiką i usiłowali znaleźć nowego odbiorcę swoich produktów. Podczas przywoływanej już konferencji 1936 roku Łukasiewicz i Salamucha przekonywali słuchaczy, że logika matematyczna nie zawiera owych idei obcych katolicyzmowi. Łukasiewicz czynił to bardziej systematycznie. Prezentował i bronił swojej słynnej tezy o neutralności światopoglądowej logiki. Wyraźnie starał się przy tym pokazać, że logika matematyczna nie ma konsekwencji neopozytywistycznych ani w ogóle nominalistycznych, a nawet delikatnie sugerował jej wydźwięk teistyczny. Wykład Salamuchy zmierzał do tego samego celu, stosując bardziej historyczną metodę perswazji. Zmierzał do pokazania, że logika matematyczna jest logiką w tym samym sensie, co logika tradycyjna, tyle że jest lepszą wersją logiki. Słuchacze domyślnie godzili się bowiem z obecnością logiki Arystotelesa i logiki scholastycznej w korpusie teologii. Logika matematyczna była więc prezentowana jako doskonalsza wersja tamtej logiki. $Z$ drugiej strony Drewnowski starał się pokazać, że stosowanie wszelkich kanonów logicznych w języku naukowym należy do standardu naukowości, a nie do głoszonych treści, czyli jest składnikiem metody. Tym sposobem nowa logika została przedstawiona słuchaczom, żyjącym w ogniu sporów modernistycznych, jako idea, która nie tylko nie jest wroga ani obca katolicyzmowi, 
ale jako jego integralna część, a nawet potencjalne narzędzie walki z owymi obcymi ideami ${ }^{48}$.

\section{BIBLIOGRAFIA}

Arnold C., Mata historia modernizmu, WAM, Kraków 2009.

Bocheński J.M., Tradycja myśli katolickiej a ścisłość, w: Myśl katolicka wobec logiki wspótczesnej, red. J. Salamucha, Księgarnia św. Wojciecha, Poznań 1937, 27-34.

Bocheński J.M., O metodzie teologii w świetle logiki współczesnej, Collectanea Theologica 21(1949), 171-192.

Bocheński J.M., Między logikq a wiarq, Les Editions Noir sur Blanc, Warszawa 1995.

Bocheński J.M., Europäische Philosophie der Gegenwart, A. Francke Verlag, Bern 1947.

Bocheński J,M., Zarys bistorii filozofii, Philed, Kraków 1993.

Bocheński J.M., Wspomnienia, Philed, Kraków 1994.

Bocheński J.M., Koto Krakowskie, Kwartalnik Filozoficzny 23(1995)1, 23-31.

Codex iuris canonici, Types Polyglottis Vaticanis, Romae 1917.

Corrêa de Oliveira P., Rewolucja i kontrrewolucja, Stowarzyszenie Kultury Chrześcijańskiej, Kraków 2017.

Drewnowski J.F., Neoscholastyka wobec nowoczesnych wymagań nauki, w: Myśl katolicka wobec logiki wspótczesnej, red. J. Salamucha, Księgarnia św. Wojciecha, Poznań 1937, 49-57.

Leon XIII, Æterni Patris, Acta Leonis Papæ, 1882, t. 1, 225-284.

Murawski R., Filozofia logiki i matematyki w Kole Krakowskiem, Filozofia Nauki 22(2014)2, 21-35.

Myśl katolicka wobec logiki wspótczesnej, red. J. Salamucha, Księgarnia św. Wojciecha, Poznań 1937.

Pieper J., Scholastyka. Postacie i zagadnienia filozofii średniowiecznej, PAX, Warszawa 1963.

Pius XI, Studiorum ducem, Acta Apostolicae Sedis 15(1923)7, 309-326.

Roszkowski W., Najnowsza historia Polski 1914-1945, Świat Książki, Warszawa 2003.

Salamucha J., O naukowq metafizyke, w: Jan Salamucha, Wiedza i wiara. Wybrane pisma filozoficzne, red. J.J. Jadacki, K. Świętorzecka, TN KUL, Lublin 1997, $51-55$.

48 Myśl katolicka wobec logiki współczesnej, dz. cyt. 
Salamucha J., Tomizm jako "philosophia perennis«, w: J. Salamucha, Wiedza i wiara. Wybrane pisma filozoficzne, red. J.J. Jadacki, K. Świętorzecka, TN KUL, Lublin 1997, 57-63.

Tkaczyk M., Cracow Circle. Theology in the Lvov-Warsaw School, w: The Significance of the Lvov-Warsaw School in the European Culture, red. A. Brożek, F. Stadler, J. Woleński, Springer, Wien 2017, 173-188.

Wolak Z., Naukowa fllozofia kota krakowskiego, Zagadnienia Filozoficzne w Nauce 36(2005), 97-122.

Woleński J., Filozoficzna szkota lwowsko-warszawska, PWN, Warszawa 1985.

Woleński J., Józef M. Bocheński i Koto Krakorwskie, w: Poza logika jest tylko absurd, red. D. Łukasiewicz, R. Mordarski, Dominikańskie Studium Filozofii i Teologii, Kraków 2014, 29-46.

Woleński J., How to Speak About History of Analytic Philosophy, w: The Significance of the Lvov-Warsaw School in the European Culture, red. A. Brożek, F. Stadler, J. Woleński, Springer, 2017, 15-27.

\title{
THE GENESIS OF THE CRACOW CIRCLE
}

\begin{abstract}
This paper is devoted to exploring the cultural background of the manifesto of the Cracow Circle, a philosophical group consisting of Józef Maria Bocheński, O.P., Jan Franciszek Drewnowski, Rev. Jan Salamucha and Bolesław Sobociński. The group was mentored by Jan Łukasiewicz and Rev. Konstanty Michalski. The manifesto of the Cracow Circle aimed to apply the programme of the Lvov-Warsaw School to Catholic theology and philosophy. Within the school, special emphasis was placed on Łukasiewicz's version of the programme. The amendments to be carried out concerned: (a) refurbishing philosophical language to meet all the conditions of proper scientific discourse, (b) incorporating mathematical logic, (c) upgrading semiotics and methodology, and (d) using formal methods in philosophy. Four groups of circumstances are analysed as the milieu of the Cracow Circle at the beginning of the 20th century and in direct relation to the influential activities of its four founders: (a) esprit de l'époque, (b) state of philosophy, (c) state of logic, and (d) state of theology.
\end{abstract}

Keywords: Cracow Circle, Lvov-Warsaw School, methodology of theology, new scholasticism

MARCIN TKACZYK

tkaczyk@kul.lublin.pl

Katolicki Uniwersytet Lubelski Jana Pawła II, Instytut Filozofii, Katedra Logiki

al. Racławickie 14, 20-950 Lublin

DOI: 10.21697/spch.2019.55.2.01 